MOLESTO: Edebiyat Araştırmaları Dergisi

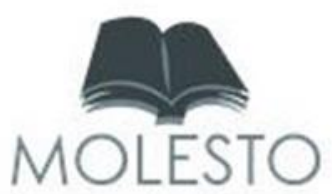

\title{
YALÇIN TOSUN ÖYKÜLERİNDE GELENEKSEL ATAERKİL ERKEK VE KADIN KIMLİKLERİNİN İNŞASI ${ }^{1}$
}

\section{CONSTRUCTION OF TRADITIONAL PATRIARCHIAL MALE AND FEMALE IDENTITIES IN YALÇIN TOSUN'S SHORT STORIES}

\section{Göksenin ABDAL*}

Öz

Bu çalışmanın amacı, Yalçın Tosun öykülerinden örneklerle geleneksel ataerkil kadınlık ve erkeklik kimliklerinin inşa ediliş yollarını ortaya koymaktır. Yazara ait yazın evreninin kısaca tanıtıldığı giriş bölümünden sonra, birinci bölümde, sünnetle inşa edilen erkeklik kavramının ele alındığ1 "Her Şey Tarih Oluyor” (Anne, Baba ve Diğer Ölümcül Şeyler, 2009); ikinci bölümde, altın günü için bir araya gelen kadınların gündelik yaşamının anlatıldığı "Altın Günü” (Peruk Gibi Hüəünlü, 2011); üçüncü bölümde, sürekli olarak aldatılma korkusu yaşayan bir erkek eşin şiddet eğilimini merkeze alan "Bir Kocanın Gizli Defterinden” (Dokunma Dersleri, 2013); dördüncü bölümde ise, bir lokanta sahibi olan Azmi Efendi ve kadın müşterisi arasındaki ilişkiye odaklanan “Güzel Yüzlü Garsonlar” (Bir Nedene Sunuldum, 2015) öyküleri incelenmektedir. Sonuç olarak, Yalçın Tosun'un, geleneksel ataerkil erkeklik ve kadınlık rolleriyle ilişkili unsurları doğrudan yansıtma ve bozuma uğratma gibi yaklaşımlarla ele aldığı ve öykülerinde bu durumun birçok izine rastlandığ fark edilmiştir.

Anahtar Sözcükler: Cinsiyet kimlï̆i, cinsiyet söylemi, yeni Türk edebiyat, kısa öykü, Yalçn Tosun.

\begin{abstract}
The aim of this study is to reveal the ways how traditional patriarchal male and female identities are constructed with examples from Yalçın Tosun's short stories. After a brief introduction of the literary universe formed by the author, in the first part, the story titled "Her Şey Tarih Oluyor" (Anne, Baba ve Diğer Ölümcül Şeyler, 2009), which describes the male identity formed by the act of circumcision in detail, is analyzed; in the second part, the story titled "Altın Günü" (Peruk Gibi Hüzünlï, 2011), which portraits a day for the gold saving ritual among women, is analyzed; in the third part, the story titled "Bir Kocanın Gizli Defterinden" (Dokunma Dersleri, 2013), which is centered on a husband's tendency to commit violence in the case of being cheated on, is analyzed; in the fourth part, the story titled "Güzel Yüzlü Garsonlar" (Bir Nedene Sunuldum, 2013), which focuses on the relationship between a female customer and the restaurant owner Azmi Efendi, is analyzed. As a result, it is found out that Yalçın Tosun handles the elements related
\end{abstract}

\footnotetext{
${ }^{1}$ Bu çalışma, İstanbul Üniversitesi Sosyal Bilimler Enstitüsü Kadın Çalışmaları Anabilim Dalı'nda 16 Ağustos 2017 tarihinde savunulan Yalçın Tosun Öykülerinde Toplumsal Cinsiyetin İnşası başlıklı tezden türetilmiştir.

* Arş. Gör., Istanbul Üniversitesi, Çeviribilim Bölümü, abdalgoksenin@gmail.com.
} 
to traditional patriarchal male and female identities by either directly reflecting or deconstructing them, and that many traces of this situation can be found in his short stories.

Keywords: Gender identity, gender discourse, contemporary Turkish literature, short story, Yalçn Tosun.

\section{Giriş}

1977 yllında Ankara'da doğan Yalçın Tosun, lisans eğitimini Galatasaray Üniversitesi Hukuk Fakültesi’nde tamamlamıştır. Hâlen İstanbul Bilgi Üniversitesi Hukuk Fakültesi’nde öğretim görevlisi olarak görev yapmaktadır. 2009 yılında Yapı Kredi Yayınları tarafindan yayımlanan ilk kitab1 Anne, Baba ve Diğer Ölümcül Şeyler, 2011 y1lında Notre Dame de Sion Öykü Ödülü’nü kazanmıştır. Yalçın Tosun, Anne, Baba ve Diğer Ölümcül Şeyler kitabında yer alan öykülerinde, aile, anne-babalık ve toplumsal yaşam ekseninde çocukluk, ilk gençlik ve yetişkinlik dönemlerindeki karakterlerin yaşamda var olma veya benliğini yitirme süreçlerini ele almış ve toplumsal cinsiyet normlarını ve bunların bireylerin yaşamları üzerindeki etkilerini tartışmaya açmıştır.

Yazarın ikinci kitab1 Peruk Gibi Hüzünlü 2011 yllında Yap1 Kredi Yayınlar1 tarafından yayımlanmış ve 2012 yılında Sait Faik Hikâye Armağanı'nı kazanmıştır. Yazar, Peruk Gibi Hǚünlü kitabında yer alan öykülerinde, bireyin toplumsal, kültürel, geleneksel kalıplar karşısında kendi olma mücadelesini, erken dönemde keşfedilen cinselliği, flört ve akran şiddetini ve platonik aşk1 anlatmıştır.

Yazarın üçüncü kitabı Dokunma Dersleri, 2013 yılında yine Yapı Kredi Yayınları tarafından yayımlanmıştır. Dokunma Dersleri'nde yer alan öykülerde, kurgusal bir kimlik unsuru olarak toplumsal cinsiyet, cinsel kimliklerin inşası, açılma, cinsel kimliğini gizleme gibi temalara ağırlık verilmektedir.

Yazarın son öykü kitabı Bir Nedene Sunuldum 2015 yılında Yapı Kredi Yayınları tarafından yayımlanmış ve 2016 yılında Yunus Nadi Öykü Ödülü'nü almıştır. Bir Nedene Sunuldum'da yer alan öykülerde, ikili ilişkilerdeki cinsel dürtü ve erotik arzu temalarına odaklanılmakta ve toplumun cinselliğe, farklı cinsel kimliklere bakış açısına yer verilmektedir.

Yazarın şiir türünde yazdığı son kitabı Kendini Tutan Su, 2016 yılında Sel Yayıncılık tarafından basılmıştır ancak çalışmanın ana eksenini Yalçın Tosun “öyküleri” oluşturduğundan, söz konusu şiir kitabı bu çalışmada incelenecek eserler arasına dahil edilmemiştir. 
Çalışmada yer verilen öykülerin incelemesine geçmeden önce, Yalçın Tosun'un yazınsal ürünlerine dair bir çerçeve çizmek ve öykü kitaplarının içeriğiyle ilişkili kısa bir bilgi vermek yerinde olacaktır.

\section{Yalçın Tosun'un Yazın Evreni}

Yalçın Tosun'un yazın dünyası ele alındığında, yazarın öykülerinde insanın farklı hâllerini ele aldığı ve insanlığa dair bir panorama çizdiği dikkat çeker. Hatice Tosun, yazarın, Anne, Baba ve Diğer Ölümcül Şeyler'de "anlatmak istediğini direkt vermek yerine sezdirmeyi tercih et titĭ̈ini]” ve "yaralar, çocuğu,

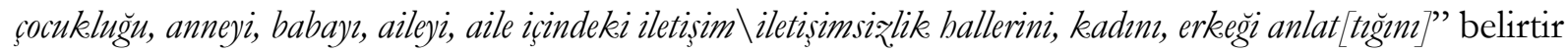
(2015). Bu anlamda, okurun bilinçaltında yer etmiş ancak yaşam yolculuğu boyunca gizlemiş ve davranışlarına yansıtmaktan kaçınmış olabileceği travmalar ve toplumsal cinsiyet kavramıyla ilişsili baskı mekanizmaları kitap içerisinde kurulan öyküler yoluyla okura yansıtılmaktadır.

Peruk Gibi Hüəünlü başlıklı kitaptaki öykülerde, öznel durumların ve kişisel yaşanmışlıklar üzerinden bireyin var olma mücadelesinin anlatıldığı görülecektir. Kitap içerisinde, ensest ilişkiden flört şiddetine, aile içi şiddetten cinsel ayrımcılık davranışlarına kadar çok çeşitli konular işlenmektedir. Yalçın Tosun, yukarıda sözü edilen konuları, toplumsal cinsiyet normlarının beraberinde getirdiği kısıtlayıcı ve sınırlayıcı bakış açısından farklı bir yöntem kullanarak ve cinsiyet eşitliği olgusuna vurgu yaparak anlatmayı seçer; bu sayede, öykülerin okur üzerinde etki birakma olasıllğı da artar. Kadir Aydın, Peruk Gibi Hüzünlǜde Yalçın Tosun'un “çocuklarn masum dünyalarndan büyüdükçe acı çeken ve çektiren yaşamlarna, kadınlarn altm günlerindeki kaygılarnndan geleneksel topluma aykur cinsel terciblerine, gençlerin kendilerini bulma, gerçekleștirme yolunda çektikleri sancilara kadar her duyguya iddiasız, bir anlatımla yaklas [tı̆ğm]”, ileri sürer (2013).

Dokunma Dersleri kitabında ise, yakınlaşma ve uzaklaşma duygularıyla ilişkili izlekler de öykülere dahil edilmektedir. Yazar, Dokunma Derslerinde, yakınlaşma ve uzaklaşma temalarını bireyler ve toplum arasında kurulan ilişkiler üzerinden anlatmayı tercih etmiştir. Bu noktada, öykülerin, farklılık ve cinsel çeşitlilik konularında farkındalık uyandırma ve ataerkil algıyı değiştirme amacını taşıdığı düşünülebilir. Hikmet Hükümenoğlu, Dokunma Dersleri kitabıyla ilgili “gündelik aşk meseleleri, siradan tutkular, merak, çekingenlik, bir an belirip bir an sonra uçu giden cinsel arzular, sadece heteroseksüel kahramanlarm tekelinde kalmamali" değerlendirmesini yaparken, Yalçın Tosun'un cinsel kimliklere yaklaşımını da ele almış olur (2013).

Bir Nedene Sunuldum başlıklı eserde, yazar, erkekliği hayatlarının merkezine yerleştiren bireyleri, ekonomik, psikolojik, fiziksel şiddetin en önemli hedefi haline gelmiş kadınları, 
kimliklerini gizlemek durumunda kalan eşcinselleri, toplumsal yaşamın çeperine itilen ve orada var olma mücadelesi veren transseksüel bireyleri ve onların yaşam deneyimlerini önceliği haline getirmiştir. Murat Yalçın, Yalçın Tosun'un kitapta kurduğu dünyayı şu şekilde değerlendirir (2015):

Kitapta yer alan yirmi öykü de insan dürten, rahatsı̨ eden öyküler. Öykülerin çoğunda cinsellik dürtüsünün insan psikolojisi üzerindeki etkisi görülmekte. Anlatılanlardan anlaşılacağı gibi Yalçn Tosun konu itibariyle de hayli ilginc noktalara temas etmiș. Üz̧erinde sılkşa durulmayan bususlar, görmez̧den gelinen meseleleri cesurca kaleme almış ve kucağımız̧a atıvermiş. Monotondan kaçmaya çalsşan ama bir fasit çemberde dönen

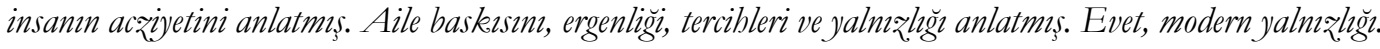

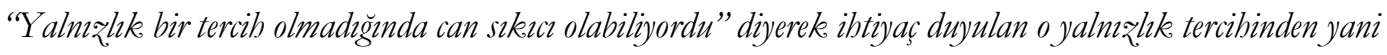
bir tür modern inz̧ivadan söz. etmiş. Bireyin tercibleri karşsssnda ailenin-toplumun katı tavrm anlatmıs buna rağmen bireyin bildiğini okuduğundan ve o kendine özgü giz̨li hazlarndan babsetmiş. Insann o en mahrem duygularna sızmıs yazar ve bunu okuyucuyla paylasmakta beis görmeyip yakaladĭg bu güglü damardan derinlikli öyküler devşirmiş.

Bu çalışmada, Yalçın Tosun'un dört öykü kitabından seçilen ve geleneksel ataerkil kadınlık ve erkeklik hâllerini yansıtan dört öyküye odaklanılacaktır. Anne, Baba ve Diğer Ölümcül Şeyler kitabından sünnet teması ekseninde erkek kimliğinin inşasını örnekleyen "Her Şey Tarih Oluyor," Peruk Gibi Hü̊ünlü kitabından özel alan ve kamusal alan ayrımına dayalı kadın kimliğinin inşasını örnekleyen “Altın Günü,” Dokunma Dersleri kitabından şiddet ve erkeklik arasında kurulan ilişkiyi konu alan "Bir Kocanın Gizli Defterinden" ve Bir Nedene Sunuldum kitabından da tek başına ayakta kalmaya çalışan bir kadının öyküsünü işleyen “Güzel Yüzlü Garsonlar” başlıklı öyküler bu bölümün ana eksenini oluşturmaktadır.

\section{"Her Şey Tarih Oluyor"}

Anne, Baba ve Diğer Ölümcül Şeyler başlıklı kitaptan alınan öyküde, Halil adlı bir karakterin sünnet anında yaşadıklarından öykü zamanına değin devam eden travma, bu travmanın eşiyle kurduğu ilişki üzerindeki sonuçları, yaşamının her alanında karakterin peşinden ayrılmayan travmanın karakterin yaşama dair bakış açısına etkileri anlatılmakta ve toplumun sünnet yoluyla erkeklik olgusuyla kurduğu ilişki ve ataerkil bakış açısı eleştirilmektedir. Öykünün başkahramanı konumundaki Halil'in, "adam” olmak, erkek olmak, toplumun çerçevesini çizdiği erkeklik kavramından payını almak konusunda çekinceleri vardır ve öykü boyunca sorular sorarak kendini sorguladığ1 görülür.

Sünnet kavramı, bir yandan toplumdaki erkeklik algısının somut bir biçimde inşa edilmesini simgelerken, bir yandan da erkekliğin maddi dayanaklarından birini oluşturur. Erkek cinsel organı 
taşıyan bir bedenin toplumsal anlamda tamamlanması ve gerçekleştirilmesi açısından en önemli eylemlerden biri halini alan sünnet, öykü içerisinde Halil'in çocukluktan beri yaşadığı travmayı anlatmak için simgesel bir eyleme dönüştürülmüştür.

Sünnet kavramı çevresinde ele alınan bir toplumsal kimlik deneyimi olarak erkeklik, toplumsal cinsiyet kavramıyla koşut olarak gerçekleştirilen normatif davranış kalıplarıyla ilişkilendirilir ve daha somut bir düzlemde ataerkinin kurulmasına ve hegemonik erkeklik kavramının gündelik yaşam içerisinde konumlandırılmasına hizmet eder. Bu açıdan, öykü içerisinde, sünnet eyleminin, erkeklikle ilişkili törensel bir eylem olarak şu şekilde ele alındığı fark edilecektir:

Halil, korkmasana yahu. Erkek adam korkar mi iğneden, bışaktan? Hem adam olacaksın oğlum. Çıksana masann altmdan. Halil, kizdorma beni. (Tosun 2009, 56)

Sünnet eylemiyle tanımlanan ve somutluk kazanan fiziksel bir özellik olarak erkeklik kavramı ele alınırken, toplumun erkekliğe dair algısının fiziksel boyutunu oluşturan penise de göndermede bulunulur. Kadınlık organı vajinanın karşısına konumlandırılan penis, bu noktada, erkekliğe ait bir imge olarak öykü içerisinde yerini alır. Öyküdeki Halil karakteri, sünnet olmayı reddetme davranışı göstererek, okura bireyler ve toplum arasında kurulan bu güç ilişkisini de gözden geçirme olanağ1 sunar. Halil karakterinin toplumun "adam” olmak olgusuyla eşleştirdiği davranış kalıplarıyla ilgili sorgulaması bu güç ilişkisinin bireyler üzerindeki etkisini şu şekilde ortaya koyar:

Hem adam olmak ne demek? Herkesin istediği gibi olmak, beklenen, ögrretilmis tepkileri vermek, yasalara uymak ya da yalan söllememek mi? Çok kü̧̈ükken almıștm bu karar. "Ben adam olmuycam" diye bağrrmışım masanın altında korkudan titrerken. Çükümün ucu gidince adam olacakmısım, peb! (Tosun 2009, 56)

Judith Butler (1993, 3), “öænenin olusumunun biyolojik cinsiyetle ilişkili normatif yapıyla özdeslesmeyi beraberinde getir[diğini]” ve "bu özdeşleșme sirasinda bireyin reddetme ve inkâr davranıs̆ göstermesinin kaçınlmaz. ol[duğunu]” belirtir. Buna göre, Halil karakteri, öykü içerisinde, bir yandan erkeklikle ilgili davranış kalıplarını sorgularken bir yandan da fiziksel bir erkeklik unsuru olarak penisin ve biyolojik cinsiyetin sınırlılığına dair bir eleştiride bulunmaktadır. Erkekliğin biyolojik bir unsur olarak penisle sınırlandırılması olgusu, Halil karakteri yoluyla okura ulaştırılmıştır.

Sünnetle temsil edilen kurgusal erkeklik kimliğinin bir diğer tamamlayıcı unsuru da yönetim ve sahip olma yetkileridir. Bu durumun yansımalarını, Halil karakterinin eşiyle ve diğer kadınlarla kurduğu ilişkilerde görmek mümkündür. Yukarıda sözü edilen yönetme ve sahip olma yetkileri, toplumdaki erkeklik algısının da temel unsurları arasında sayılmaktadır. Söz konusu erkeklik algısının 
beraberinde getirdiği düşünce biçiminin, Halil karakterinin iç sesinde şu şekilde yer bulduğu görülecektir:

Sanki iki hafta önce koltuğun yeri değissti diye bütün evi ayağa kalderan aksi ibtiyar ben değildim. (Tosun 2009, 55)

Halil karakteri öykü içerisinde yukarıdaki şekilde merkeze yerleştirilirken, bir yandan da toplumsal yaşamı kuran ve toplumsal yaşamdaki hegemonik cinsiyet imgelerinin devamlilı̆ı̆nı sağlayan erkeklik kavramı da okur karşısında tartışmaya açılmış olur. Erkeklik ve hegemonya kavramları konusunda, Janet Holmes "kişinin kendisini güçlü ve lider özellikleriyle konumlandırması[nm], otorite ve kararliluğ alttan alta bünyesinde barndiran söylem yöntemlerini ve erkeklikle iliskili özellikleri de içer[diğini?" belirtir ve bu durumu "direktif verme, toplantılar açma ve kapama, tartışmayı yürütme" gibi eylemlerle ilişkilendirir $(2014,439)$. Halil karakterinin, eşine, üst kat komşusu kadına ve eve temizliğe gelen kadına karşı buyurgan tavırlarında yukarıda da sözü edilen ataerkil düşüncenin erkekliğe atfettiği üstün hiyerarşik konumun da etkisinin olduğu görülmektedir.

Halil'in sünnetle birlikte yaşadığı travma, onun diğer kadınlarla ilişkilerinde de büyük bir etkiye sahiptir ve ilişkilerinde iç huzursuzluğu yaşamasının temel nedeni olarak öyküye yansıtılmıştır. Sara Mills, "bireylerin özellikle kadinlar söz, konusu olduğunda bir buحursųluk yaşa[diğmı]” ve "bu durumun

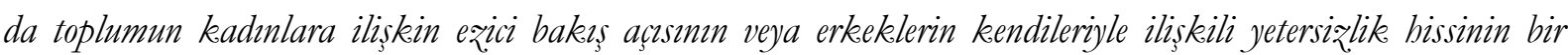
göstergesi ol[duğunu]" belirtir $(2004,86)$. Bu duygunun beraberinde getirdiği sorgulama hali, öykünün başka bir kısmında Halil’in yardımcısıyla ilişkili düşüncelerinde de kendini gösterir:

Mesela annesi ölüm döseğindeyken ve bana sarlmış ağlarken, yardmomomn memelerini gögsü̈mde bissetmekten ve ayn zamanda ǚülmüs rolü yapmaya devam ederek sirtımı swąlatmaktan bic gocunmuyorum. Gencken bölle bir durum olsa, sarlmayn ve teselli ediyormus gibi yapmayn filan birak, mubtemelen buraya gelmezdim bile. (Tosun 2009, 57)

Don Kulick, "kişilerin belirli arzu davramıslar sergilerken kültürel olarak kodlanmıs davranıs kahplarndan yardım almasinm kaçınlmaz ol[duğunu]” ve "bu kodlarn da toplumsal yaşamda dolaşımda olan belirli göstergeler yoluyla inșa edil[diğini]” belirtir (2014, 71). Aynı durum, Halil karakterinin, başka kadınlarla kurduğu ilişkinin fiziksel boyutlarını düşünürken işin içine toplumsal davranış kalıplarını da katmasıyla ve erken yaşlarıyla şimdiki halini karşılaştırmasıyla anlaşılırlık kazanmaktadır. Kadınlarla ilişki kurdukça değişen ve kadınlara dair algısı da iyileşen Halil karakteri, zamanla değişen davranış kalıplarını ve başkalaşan algıyı okura yansıtma konusunda aracı bir konumdadır. 
Halil karakteri, kadınlarla her karşılaşmasında kendi davranışlarını da gözden geçirme ihtiyacı hissetmektedir. Halil'in, komşusu Nihan Hanım'ın balkonuna bakarken içinden geçen düşünceler bu durumu kanıtlar niteliktedir. Söz konusu kendini gözden geçirme ihtiyacına, toplumsal cinsiyet unsurunun kadınlık alanına da gönderme yapılarak, öykü içerisinde şu şekilde yer verilmiştir:

Nihan Hanm'a surf bu yüzden çok sayg duyuyordum; zengin iç çamaşın koleksiyonunu öteki kadinlar gibi gözlerden uzaklarda saklamak istememisti ne de olsa. (Tosun 2009, 57-58)

Yukarıdaki alıntıda, sünnetle başlayan bir erkeklik travması yaşayan Halil, kendi davranışlarını Nihan Hanım'ın davranışlarıyla kıyaslamaktadır. Halil, kamusal alanda bir erkeğin ayrıcalıklarına sahip olduğu halde kendini ifade etmekten çekinmekte, Nihan Hanım kadınlığına rağmen cinselliğini daha özgür bir biçimde yaşamaktadır.

Arzunun ve cinsel dürtülerin toplumsal bir denetim mekanizması içerisinde değerlendirilmesi, bireylerin cinselliğe dair algılarının da toplumsal yaşam tarafından şekillendirildiği düşüncesini beraberinde getirir. Öykü boyunca sünnetle ilgili travmasının cinselliği açıça yaşamasına engel olduğu izlenimi vurgulanan Halil karakteri, söz konusu eksikliğini, etrafindaki kadınların hayalleriyle gidermeye çalısacak ve erkekliğini şu şekilde tamamlayacaktır:

Gece baș ağrnm tuttu. Ağrn kesici de kalmamıs. Aysun ve Hanm'la ayn yatakta olduğumu hayal ettim bir an, sonra bu edepsiz, hayalin sarboșluğu geçti ama baş ağrrm aynen duruyordu. (Tosun 2009, 58)

Nasıl ki hayaller bir tür kaçış noktası ve sı̆̆ınma alanıysa, çocukluk da Halil için bir kaçış alanı olarak karşımızda durmaktadır. Ancak Halil karakteri, sünnetle erkekliğe adımından bugüne değin ataerkil düzenle ilişkilendirilen davranış kalıplarını ve düşünceleri sürekli olarak sorgulamış ve onlardan kaçınmaya çalışıştır. Davranış kalıplarının sorgulanmasıyla ilişkili olarak, Butler, "sergilenen șeyin arkada yatan, görünmeyen ve bilinçaltın temsil eden șeyi giə̌leme amacı taşı [dığı] ve sergilenen davranısın bir davranışa indirgenmesinin de yanlş ol[acă̆g]” yorumunu yapar (1993, 234). Bu nokta, gündelik yaşamda çok fazla dile getirilmeyen normatif yapının, düzen koşullarının ve ataerkil yaşam deneyimlerinin genel geçer özellik taşımadığını ve sorgulanabilir olduğunu okura göstermesi açısından önem taşır.

Sonuç olarak, öyküde, Halil karakteri merkezde olmak üzere, diğer yan karakterler yoluyla yazınsal bir alan inşa edilmektedir. Halil karakteri, inşa edilen yapı içerisinde bir kimlik unsuru olarak erkekliği temsil eder ve erkekliğin toplumsal düzlemde yarattığ1 etkileri ve bu etkiler sonucunda şekillenen bireylerarası ilişkileri okura yansıtır. Yazınsal özellikler ekseninde ele alındığında, Gilles Deleuze'ün, "farkh yapısal özelliklere dayah olarak gelisen gerçeklik ve ideoloji, öz̨deslike kurma ve çeliski Cilt 1 / Say 1

Aralık 2018 
kavramlarmm, yazarm yą̧ma etkinliği ve süreci içerisinde çeşitli kurgusal benlik özelliklerini yansitmaya aracıllk et [tiğgị” şeklindeki düşüncesi (2003, 192), yukarıdaki durumu destekler nitelik taşır. Deleuze’ün öne sürdüğü düşünceden hareketle, Yalçın Tosun'un, gözlemci kimliği aracıllğıyla, gerçek olan ve kurgusal olan arasındaki ayrımı bulanıklaştırarak, okurun öyküyle daha sıkı bir biçimde ilişki kurmasını mümkün kıldığ1 görülmektedir.

Bir sonraki alt bölümde, Peruk Gibi Hü̊ünlü kitabından “Altın Günü” başlıklı öykü ele alınacak ve geleneksel ataerkil kadınlık tanımı tarışmaya açılacaktır.

\section{“Altın Günü”}

Peruk Gibi Hüzünlü kitabından alınan öyküde, evinde altın günü düzenleyen Mehpare Hanım’ın burun karıştırma alışkanlığı olan kız çocuğunun bakış açısından faydalanılarak, Mehpare Hanım ve altın gününe gelen kadınlar arasındaki ilişkiler ve söz konusu kadınların yaşam öykülerinden kesitler sunulmaktadır. Bu eksende, öykü içerisinde, kız çocuğu ve babası arasındaki ensest taciz gibi sarsıcı ve şiddetli bir duruma ve bu durumun anne ve kız çocuğu arasındaki ilişki üzerindeki yansımalarına da yer verilmiştir.

Sırasıyla, Mehpare Hanım’ın kızının öyküsü, komşulardan birinin kızı olan ve zekâ geriliği yaşayan Suna'nın öyküsü, eşi sınıf atlayınca kendisi de Behiye'likten Behiye Hanım'lığa terfi eden Behiye Hanım'ın öyküsü, İsmet ve Fikret kız kardeşlerin öyküsü anlatılır ve öykü, kadınların kişisel yaşam deneyimlerini anlatıldığı bir kadınlık öyküsüne dönüştürülür.

Öykü, başlı̆̆ından da anlaşıldığı üzere, altın günü yapmak için bir araya gelen, aynı muhitte yaşayan kadınların birbiriyle kurdukları ilişkilere odaklanmaktadır. Bu açıdan altın gününün de düzenlendiği özel alan, geçmişten günümüze kadınların alanını yansıtan bir mekân olarak öykü içerisine dahil edilmiştir. Öykünün karakterlerinin kadınlardan oluşması, yazarın erkeklere atfedilen kamusal alan ve kadınlara ayrılan özel alan arasındaki ayrımı yansıtma isteğini de gözler önüne serer.

Öykü, Mehpare Hanım’ın, kadınlara biçilen özel alanı inşa etme görevinin de yansıması sayılabilecek altın günü hazırlıklarıyla açılır:

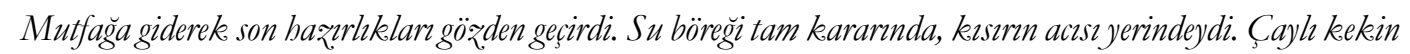
tarçn çok mu kaçmıstı acaba? "Yok camm” dedi, "Her zamanki gibi işte. (Tosun 2011, 16)

Mehpare Hanım'ın alın günü için hazırladığı yemeklerle ilişkili yukarıdaki kaygısı, diğer kadın misafirler karşısında "makbul kadın” olma çabasını ve özel alandaki kadınlığa ilişkin beklentileri karşılama eğilimini de yansıtır. Bu noktada, normatif davranış biçimleri ve toplumsal beklentiler, 
hem kamusal alanın dışarıdan etkisiyle hem de özel alanda inşa edilen beklentiler yoluyla kadınların yaşamlarına etki eder.

Davranış biçimlerine dair beklentiler bağlamında, Donald E. Hall, “otoriter sistemin, toplumsal beklentiler, belirli rollerin tanım ve kendini ifade etme kavramlar üzerinden ăgrrlğğm hissettir[diğini]" belirtir $(2003,118)$. Ortak alandaki yaşam deneyimleri, öykülerdeki karakterlerin bakış açılarına ve davranış biçimlerine de yansıtılmıştır. Bu açıdan, toplumun farklı kesimlerinden gelen ancak benzer sorunlar yaşayan, benzer algılara sahip olan ve benzer davranışlar sergileyen kadın karakterler, “Altın Günü” öyküsü ekseninde özel alanda bir araya getirilmiştir.

Behiye Hanım'ın diğer kadınlarla kurduğu ilişki, yukarıda sözü edilen davranış biçimlerinden nasibini almış ve eşinin, çalıştığı süpermarkette işletmeci konumuna yükselmesiyle Behiye Hanım da arkadaşları arasında sınıf atlamıştır. Yukarıdaki durum, hegemonik cinsiyet ilişkileri ekseninde, öykü içerisinde şu şekilde ele alınmıştır:

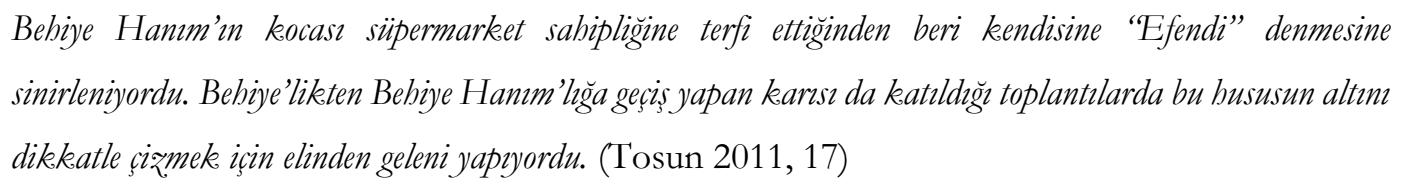

Yukarıdaki alıntı, erkeklik üzerinden kazanılan konumun toplum nezdindeki önemini ironik bir biçimde ele almakta ve bu durumu, kadınların hayatlarında karşılarına çıkan sorunları da dahil ederek gerçekçi bir biçimde okura yansıtmaktadır. Eşinin konumuyla kendi konumu da yükselen Behiye Hanım karakteri yoluyla, kamusal alanda evlilikle inşa edilen sınıfsal ilişkiler de eleştirilmiştir.

Evlilik kavramıyla kurulan cinsiyetlerarası hegemonik ilişkiye yapılan göndermelerden sonra, hayatları boyunca evlenmemiş olan, ancak bu hallerinin de garipsendiği okura hissettirilen üst kattaki bekâr komşular Fikret ve İsmet kardeşlerden söz edilir. Fikret ve İsmet kardeşler, hiç evlenmedikleri için diğer kadınlar tarafından hem garipsenir hem de küçümsenirler. Diğer kadınlar, evlilik olmadan gerçekleştirilen her eylemin yersiz olduğunu hissetmektedir. Bu durum, öykü içerisinde şu şekilde ele alınmıştır:

Arkasindan Fikret ve Ismet kardeşler geldiler. Bunlar üst katta oturan ve biç evlenmemiş iki kız kardeşsti. Altmışlarndan gün almışlardı ama yaşlarm pek göstermę̧lerdi. (Hangisi daha büyǚktü kimse bilmę̧di.)

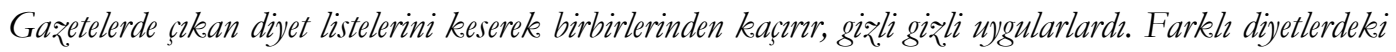
yemekleri ayr aym pişirir, babalarndan kalan emekli aylhklarm avokado, brokoli, yağsız, tavnk göğsü ve peynirlere yaturarak gę̧inir giderlerdi. Zargana misali zaynf olmalarna rağmen en büyük zevkleri baftada bir tartya çıkarak kimin daha fað̧la kilo verdiği konusunda yarışmaktı. (Tosun 2011, 18) 
Yukarıdaki alıntı okunduğunda, bekâr/evlenmemiş kadınların kendilerine vakit ayırmak konusunda daha özgür oldukları, kendiliklerini inşa etmede bir erkeğin varlığına ihtiyaç duymadıkları izlenimi uyansa da, evlilik dışında da erkek egemen baskının devam ettiği düşüncesi okura yansıtılmaya çalışılmaktadır. İsmet ve Fikret kardeşler, hâlâ babalarından kalan emekli aylıklarına bağlıdırlar ve kadınlıkları konusundaki beklentileri, kilolarını kontrol altında tutma çabaları ile karşılamaya çalışmaktadırlar. Ancak yine de diğer kadınlara oranla daha özgürdürler. Çünkü herhangi bir eşin veya çocuğun sorumluluğunu taşımazlar. Ataerkil toplum düzeni, evlilik kavramına yüklediği anlamla, evlenen kadınların yalnızca eşlerinin değil, çevrelerindeki diğer bireylerin de sorumluluklarını taşımakla yükümlü olduğu düşüncesini kadınlara dayatır.

Bu durum, Suna'nın annesiyle babası Yusuf arasında kurulan ilişkide de kendini gösterir. Evliliğin kadınlara dayattığı sorumluluklar, evlilik boyunca Suna’nın annesinin taşıdığı sorumluluk üzerinden kavramsallaştırılmış ve öykü içerisinde şu şekilde ele alınmıştır:

İstasyonda ikinci şef olan Yusuf çok istemişti çocuk yapmalarm. Ona kalsa bu dünyada çocuk yapmaya gelene kadar uğrasacak ne çok sey vardl: Komşular, komşularn çocuklar ve gelinleri, çeyizlleri ve dünürleri, ev sahipleri ve kiracıları, alacaklar ve borçlar vard mesela. (Tosun 2011,20)

Kadınların gerek evliliklerinde gerekse de evlenmeden önceki aile ilişkilerinde ezilmeleri, kendileri tarafından toplumsal düzenin doğal bir parçası olarak yorumlanmaktadır. Özel alan ve kamusal alan ayrımıyla da doğallaştırılan bu ezilme durumuna dayanarak, Donald Hall, "yapılan seģimlerin daima koşullandırlmıs olduğunu ve sorumluluk duygusunun kadinlarn yaşamı boyunca sürekli olarak kendini göster[diğgin]]" vurgular $(2004,126)$. Yusuf karakteri arac1lığılla ele alınan Suna ve annesinin öykülerinde, bu duruma dikkat çekilmekte ve evle ilgili sorumlulukların kadınlara yüklendiği gösterilmektedir. Özel alan ve kadınlar arasında kurulan ilişki, öykünün başka bir kısmında şu şekilde ele alınmıştır:

Babam buradaymıs demek. Ne zaman geldi acaba? Peki nereye ve neden gitmişti? Neden beni görmeye bic gelmemişti? Kesin annem ižn vermemiştir gelmesine. Yoksa beni görmeden durabilir miydi big̣! (Tosun 2011, 21)

Yukarıdaki alıntı incelendiğinde, Mehpare Hanım’ın kızının, dışarıyı, bir başka deyişle, kamusal alanı babasına ait bir yer veya alan olarak tanımlarken, eve ait alanı da annesiyle ilişkili bir alan olarak gördüğünü ortaya koymaktadır. Kız çocuğunun özel alanı paylaştı̆̆ı diğer kadınlarla ilgili algısı ise henüz ayrılmadığı babasının geri döndüğünü duyan annesi Mehpare Hanım'ın fenalaşması üzerine hissettikleri bağlamında şu şekilde öyküye yansıtılır: 
Acaba baynldı mı içeride? Ama öyle olsa öteki yaygaracı kadinlarn sesini duyardım. Aman ne büyütürlerdi şimdi, sanki biç baynlan kadn görmemişler. (Tosun 2011, 21)

Özel alandaki ilişkiler üzerinden, Stuart Hall, “kültürün, hem hislerle, ilişki kurmayla, duygularla bem de kavram ve düș̈̈ncelerle iliskili ol[duğunu]” belirtirken, "akuldan geçen düşüncelerin kişinin kim olduğuyla, ne bissettiğgyle, toplumsal grupla ilişkilenme biçimiyle ilgili şeyleri de ortaya koy[duğunu]" vurgular (1997, 2-3). Öykü içerisinde, Mehpare Hanım’ın kızının aynı özel alanı paylaştı̆̆ı diğer kadınlara dair algısının, kamusal alandaki iktidarı temsil eden babasının etkisiyle şekillendiği fark edilecektir. Kız çocuğunun toplumsal bir grup olarak kadınlarla ilişkilenmek istememesinin temelinde, kadınların kamusal alanda iktidar sahibi olmamaları ve hem fiziksel hem de duygusal açıdan zayıf görülmeleri neticesinde özel alana kapatılmaları yatmaktadır.

Yukarıda sözü geçen durum, öykünün ana karakteri sayılabilecek kız çocuğunun, çok karmaşık ve şiddetli, psikolojik bir durum olan babasının ensest tacizini anlamlandıramamasına da yol açmıştır. Kız çocuğu, gerek yaşı ve bilinç düzeyi gerekse de babasıyla kurduğu ilişkiden dolayı babasının gerçekleştirdiği taciz olayını tam olarak taciz olarak algılamamaktadır. Ensest bir eylem olarak kendini gösteren taciz, Mehpare Hanım'ın fark etmesiyle önlenmiş; bu sayede, tacizi gerçekleştiren baba, kız çocuğuna zarar vermeden evden uzaklaştırılmıştır. Kız çocuğu, babasının yanlış bir şeyler yaptığını sezse de, eylemi gerçekleştiren kişinin babası olması dolayısıyla böyle bir olasıllğ̣ düşünememektedir. Kız çocuğunun taciz eylemi karşısındaki tavrı, öykü içerisinde şu şekilde yansıtılmıştır:

Arada kulağımın hemen arkasinda duran babamın ağ̊zından morlttya benzeyen garip sesler çıktiğmı batrllyorum. Sicacke nefesini kulağmmda bissediyordum. Bir șeyler yanlıs gibi geliyordu bana ama bic anlamiyordum. Buna rağmen, dünyadaki en güvenli yerde, babamın kucağındaydom işte, mutluydum. (Tosun 2011, 21)

Yukarıdaki alıntı incelendiğinde, kız çocuğunun, babasının gerçekleştirdiği taciz eylemini, bir tür "sevgi gösterisi” olarak algıladığı görülecektir. Özel alanda gerçekleştirilen bu türden bir taciz eylemi, kadınlara bırakılan bir alan olarak özel alana erkek müdahalesi ekseninde de yorumlanabilir. Kadınların özel alanda erkek egemenliğine karşı mücadele hattı çizme eylemi, Mehpare Hanım'ın kızını eşine karşı koruma isteğinde kendini gösterir. Bu sayede hem özel alandaki erkek müdahalesi sona erdirilmiş olacak hem de kızının istismar edilmesi ortadan kaldırılacaktır:

Ya kocasiyla karşılaşırsa ve adam eve dönmek, kız̨n görmek isterse ne yapacaktı? Bunu engellemek için elinden ne gelirdi? (Tosun 2011, 22) 
Özel alana gerçekleşen müdahale açısından, Bethan Benwell ve Elizabeth Stokoe, "alanlar arası smorlarm, özel alanın, kamusal alanın, devletin, kirsalın birtakım eylemleri de beraberinde getir [diğini] ve bu tür alanlar üzerinde egemenlik kuranlarn da mekânsal kimlikle yakem ilişkili ol[duğunu]” dile getirir (2006, 210). Kadınların erkek egemen yapıya karşı bir alan olarak inşa etmek durumunda kaldıkları özel alanın da ortadan kalkması, erkeklerin her iki alan üzerinde de erk kurmasını beraberinde getirebilir. Bu durum, Mehpare Hanım'ın, hem kızının hem de özel alan olarak evin üzerinde egemenlik sahibi olma isteğini göstermektedir.

Sonuç olarak, Mehpare Hanım'ın ve diğer kadın karakterlerin öykü içerisindeki konumları değerlendirildiğinde, Yalçın Tosun’un gerçeklikle kurduğu bağ ve bir yazar olarak gerçekliği olduğu gibi yansıtma özelliği de gözler önüne serilmektedir. Yazar, gerek Mehpare Hanım'ın kızının taciz öyküsünde gerek İsmet ve Fikret kız kardeşlerin yaşamlarını anlatırken gerçeklikle kurduğu bağı son derece sıkı tutar ve okurun, okudukları karşısında empati duymasına olanak tanır.

Bir sonraki başlıkta, evli bir erkeğin eşinin kendini aldatma olasıllğıyla şiddete yönelme eğiliminin sorgulandığı “Bir Kocanın Gizli Defterinden” başlıklı öykü incelenecektir.

\section{"Bir Kocanın Gizli Defterinden"}

Dokunma Dersleri kitabında yer alan öyküde, eşi tarafindan aldatılma olasıllğına karşı takıntı duygusu geliştirmiş olan bir erkeğin iç sorgulamaları okura yansıtılmakta; karakterin yaptı̆̆1 sorgulamalarla da aile ve toplum ekseninde toplumsal cinsiyet alg1sı gösterilmeye çalışılmaktadır. Öykü içerisinde, aldatma eylemiyle ilişkili “erkeklik onuru” kavramı da sorgulanmaktadır. Erkeklik ve şiddet, erkeklik üzerinden kurulan toplumsal beklentiler, kadınlıkla ilişkili beklenti ve normlar, kadın bedenine dair alg1, evlilik yaşamı, namus gibi kavramlar üzerine toplumsal düşünceler, öykü boyunca ana karakter yoluyla okura iletilmiştir.

Öykü, eşinin kendini aldatmasını istediğini ifade eden bir kocanın kendini sorgulamasıyla açılır:

Beni aldatmasın istiyorum. Karmmn. Aslnda istemek de değ̈l tam; anlatması z̧or. Şäyle diyeyim: Karmmn beni aldatmasindan o kadar çok korkuyorum ki, hemen başıma gelsin ve bir an önce bitsin istiyorum. (Tosun 2013, 16)

Toplumun erkeklerden beklediği ve erkeklerin gerçekleştirmesini istediği aile içi namusu koruma ve sürdürme eylemi, öykü içerisinde yukarıdaki şekilde dile getirilmiştir. Ataerkil düzen, ailenin ve aile içindeki bireylerin onurunu kadınların cinsel eylemlerden ve toplum içerisinde erkeklere sağlanan özgürlüklerden alıkoyulması üzerinden kurar. Benwell ve Stokoe, "sözde cezalanderma eylemlerinin toplumla kurulan mekânsal, göndergesel ve karşsllkh iliskileri sürdürme amacm Cilt 1 / Say1 4

Aralık 2018 
taşı [diğını]” belirtirken, namus ve onur kavramlarının toplum içerisindeki alg1 ve eylemler üzerindeki etkisini de ele almış olurlar (2006, 76). Benwell ve Stokoe'nun da belirttiği gibi, cezalandırma eylemleri, toplumsal yaşamda hegemonik ilişkilerin sürdürülmesi amacına da hizmet etmektedir. Öyküde çizilen şu manzara, zihinlerde yerleşmiş şiddet izleğini güçlendirmeye ve okura bu konuda duyarlık kazandırmaya yöneliktir:

Yani başımda zevkesiz, kül rengi bir fötr șapka, üstümde devetüyü bir pardösü, bir elimde kapıda brrakmayn unuttuğum, ucundan şspır şipır sular damlayan şemsiyem, öbüründe o çok sevdiğgim, teklemesi pek mubtemel revolverlerden biri olmayacak. (Tosun 2013, 16)

Yukarıdaki sahneyle birlikte, okur, daha önce okuduğu kitaplarda, izlediği filmlerde, televizyonda gördüğü programlarda, radyoda duyduğu konuşma ve sohbetlerde yer alan şiddetle ilişkili olguları zihnine çağıracaktır. Bir sonraki adımda, erkek eşin, aklından geçen şiddet eylemini şu şekilde ifade ettiği görülür:

Sevgili kanciğma kocasmdan okkali bir tokat. (Tosun 2013, 17)

Şiddet ve erkeklik arasında kurulan ilişki, bir yanıyla, ataerkil düzenin kadın bedeni üzerinde hâkimiyet kurma eğilimini de yansıtır. Yukarıdaki alıntıda sevgili ve okkeal sözcüklerinin yan yana getirilmiş olması, hâkimiyet kurna eğilimine ve erkekliği toplumsal alanda kanıtlama eylemi olarak şiddete göndermede bulunur. Stuart Hall, “erkin, yalnı̨̧ca ekonomik sömürü ve fiə̧iksel baskr olarak değil, aym zamanda daha geniş bir kültürel veya sembolik anlamda da anlaşılması gerek_[tï̈zni] ve belirli bir şsyi belirli bir yolla temsil etmek için kullamlan gücü de içer [diğini]” belirtir (1997, 259). Stuart Hall'un da belirttiği gibi, erkin temsili ve güç arasındaki ilişki, kültürel ve sembolik anlamda erkekliği tamamlayıcı unsurlardan biri halini alır. Bu aşamada, şiddet ve erk kavramlarının, öyküdeki karakterin de kendilik deneyiminin önemli oranda kurucusu haline geldiği fark edilecektir. Bu durum, öykü içerisinde, Lacan'ın ayna ${ }^{2}$ kavramıyla ilişki kurularak şu şekilde yansıtılmıştır:

Ne zaman şiddete basvurma isteği gäğsümden başıma doğru yükselir gibi olsa, sanki bir ben daha ģıar bedenimden; karşıma geçip öteki beni iə̌lemeye bașlar. (Tosun 2013, 17)

Ayna kavramından yola çıkarak kavramsallaştırılan kendilik deneyimi, erkeklik açısından toplumsallaşma ve toplumsal cinsiyet üzerinden tanımlanan erkeklik ve kadınlık rollerini içselleştirme açısından önemli bir alanı temsil eder. Bireyler, dilsel, kültürel, siyasal, ideolojik, ekonomik beklenti ve koşullara uygun olarak inşa ettikleri kendilikleri yoluyla dünyevi sorunları

\footnotetext{
${ }^{2}$ Bu bağlamda, Lacan'ın tanımlamasından hareketle, ayna, bireyin dışarıdan kendisine nasıl bakıldığı ve bu dış bakışın etkisiyle kendini nasıl gördüğü ve özdüşünümselliği nasıl gerçekleştirdiğiyle ilişkili bir kavram olarak kullanılmaktadır. Cilt 1 / Say1 4

Aralık 2018
} 
algılar ve bu sorunlara çözüm yolları ararlar. Bu açıdan, öykü içerisinde, şiddetin içselleştirilmesi üzerinden tanımlanan ve kendilik yoluyla inşa edilen erkeklik kavramının etkili bir şekilde vurgulanmış olması önemlidir. Öyküdeki ana karakterin, erkeklikle ilişkili kendilik deneyimini şu şekilde sorguladığı görülür:

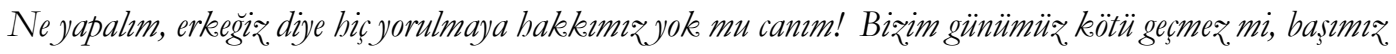

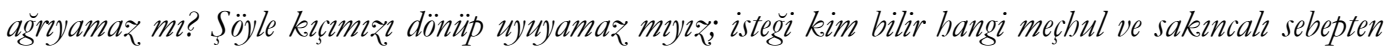
kabarmıs karmıza doğru? (Tosun 2013, 17)

Erkeklik üzerinden kurulan beklentilerin sorgulandığı yukarıdaki alıntı, erkeklik kavramına getirilen eleştirileri de içerir. Butler, "biyolojik cinsiyetin yalnıæ̧ca birinin sabip olduğu veya olmadiğg șeyi ifade etme [diğini], aym zamanda birinin görünürlük kazandiğı ve kültü̈rel olarak anlaşıllr olduğu bir bedene de karşıllk. gel[diğini]' vurgular $(1993,2)$. Yukarıdaki alıntılardan hareketle, erkeklikle ilişkili kendilik tanımının kapsamına şiddetin ve kendine ilişkin olarak kurgulanmış bir üstünlük kurgulamasını benimsemesinin girdiği söylenebilir.

Yalnızca erkeğin kendisine ilişkin bu üstünlük algısı değil, aynı zamanda başka kadınların kendi aralarında kurdukları ilişkiler de öyküde ele alınmıştır. Diğer kadınların kendi aralarındaki ilişkiler, öykünün ana karakteri sayılabilecek erkek eş tarafindan şu şekilde yorumlanır:

İsyerinden arkadaşı "Kilo mu aldın sen biraz??" demis. Regl sözciügünü ısrarla 'regıl' diye telaffuz eden,

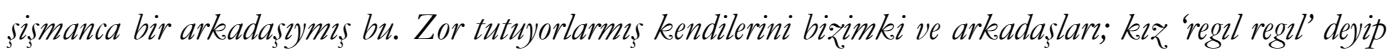

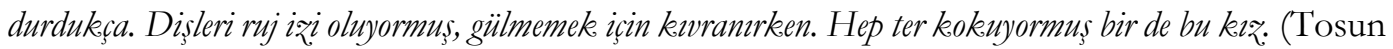
2013, 18).

Benwell ve Stokoe, "sorular kim soruyor? Eylemi kim gerçekleştiriyor? sorularmm söylemdeki rolleri anlamak açısından önemli ol[duğunu]” vurgular (2006, 112). Öyküde sorgulayan ve yorum yapan karakterin bir erkek olduğu düşünüldüğünde, söylemi oluşturanın da bir erkek olduğu, dolayısıyla yapılan yorumlarda erkeğin kendilik deneyiminden izler olması doğal karşılanmalıdır. Aynı durumun, kadın eşin bedeni söz konusu olduğunda şu şekilde devam ettiği görülebilir:

Bal gibi kilo aldı son zamanlarda. Güzel sekilli memeleri daha da dikekat ceker oldu kilo alunca. Ayncalkkh kalçasmm zarif kavisi daha bir göz alı oldu. Gerdanndaki ak çizgi biraz daha cilveye durur, baldwrlar eteğinin altmdan dünyaya daba parlakşa bakar oldu. (Tosun 2013, 19)

Erkek eş, toplumsal yaşamda dişiliğin simgesi sayılan göğüs ve kalçalarla ilişkili yorum yaparken toplumdaki kadın bedeni algısına dair ipuçları da verir. Erkeklik algısı ve kadın bedeni arasında kurulan ilişki, bir yandan kadın bedeni üzerinde hâkimiyet kuran erkekliği, bir yandan da 
üzerinde hâkimiyet kurulan kadınlığı bir araya getirir. Bu açıdan, erkek bedeni, bir özne olarak hâkimiyet kuranı, kadın bedeni ise bir nesne olarak üzerinde hâkimiyet kurulanı simgeler.

Erkek bedeni ve kadın bedeni arasında kurulan ilişkiden hareketle, bir sonraki aşamada, ana karakter aracılığıyla evlilik yaşamındaki rollere ilişkin toplumsal bakış açısının da şu şekilde okura ulaştırıldı̆̆1 görülür:

Her evlilikte zamanla, detaylarda azçok farkl, ama temelde ayn kurallara bağh o giz̨li dil bükü̈m sürmeye başlar. Coğun kinle ve yerine getirilememis isteklerin yanı kokusunun verdiüi sanchl siz̨larla beslenen;

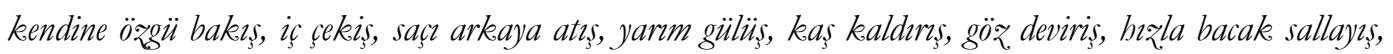
uzaklara manidar bakışlarla dahş ve benzeri değissik anlamlar bünyesinde özenle barnderan bareketlerin bir toplamider bu gizlli dil. (Tosun 2013, 20)

Hall., "beteroseksüel evliliğin ve geleneksel ev içi uygulamalarn, erkeklerin kadm bedenine egemen olduğu algrsıyla ilișkili ilkelere ve onlarn ibtiyaçlarmm, tutkularmm, güvenlik, ekonomik, güvence ve duygusal destek, gibi temel haklarmm kesin bir biçimde iblaline dayan [diğmn]” ileri sürer $(2003,161)$. Öykünün ana karakteri de eşi hakkında yorum yaparken, ataerkil düzenin kendisine bahşettiği siyasal, ekonomik, ideolojik ayrıcalıklarla hareket eder ve hegemonik bakış açısını düşüncelerine yansıtır. Bu açıdan, ana karakter olan erkek eşin kadınlarla ilgili yorumları ve düşünceleri ile ataerkil düşünce sisteminin erkekliğe atfettiği özgüven arasında bağ kurulabilir. Bu bakımdan, kendilik deneyimi ve şiddet eylemi tamamlayıcı rol üstlenir. Bu durum, öykü içerisinde şu şekilde yansıtılmıştır:

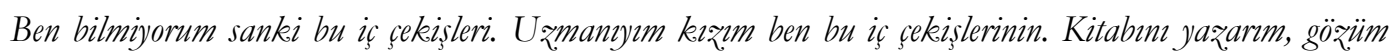
kapal. Yine de anlamama rağmen renk vermedim, iyice soktum burnumu kitabıma. (Tosun 2013, 20)

Yukarıda alıntılanan kısımda, ana karakter, ataerkil düzenin kendine verdiği alana ve ayrıcalıklara dayanarak, eşinin psikolojik durumu hakkında kolayca çıkarım yapabileceğini iddia etmektedir. Bu durum da, "erkekler mantıklıdır ve ruhun akılla ilgili kısmını temsil ederler" düşüncesine ve "kadınlar duygusaldır ve ruhun duygularla ilgili kısmını temsil ederler" düşüncesine temel teşkil eder. Hélène Cixous'nun (Lodge 1995, 287) “etken/edilgen, güneş/ay, kültür/doğa, gündüz/gece, baba/anne, kafa/kalp” şeklindeki kavramsallaştırmasından hareketle, ikili zıtlıklar, erkek ve kadın arasındaki kişisel, fizyolojik, duygusal farklılıklarla ilişkili olarak kabul edilmiş karşıtlığı da yansıtmaktadır. Söz konusu kavram, iki cinsiyet arasındaki ayrımları daha da belirgin hale getirmektedir. İkili zıtlıkların beraberinde getirdiği farklılıklara dayalı düşünce biçimi, öyküde şu şekilde ele alınmıştır: 
Ah, arzularm asla sakimlacak ve saklanacak bir sey gibi görmeyen, tutkusunu bir mücevher misali gö̆ssünde taşımasım bilen karm. Beni aldatacağma dair şüphelenmemi gerektirecek hiçbir şey yapmamıs olan karm. Yine de bir gün beni aldatacağına emin olduğum karm... (Tosun 2013, 22)

Yukarıdaki alıntıda da sözü edildiği gibi, kadının denetim altında tutulması gerektiği düşüncesi, toplumda cinsiyet ayrımcıllğının ve kadına yönelik şiddetin de en temel nedenlerinden biri sayılmaktadır. Kadın bedenine ve duygusal alanına yönelik olarak gelişen siyasal, ekonomik, ideolojik, dinsel ve toplumsal baskılar, kadının özgürleşmesi önünde en büyük engelleri teşkil eder. Bu türden baskıların nedenselliği, ana karakter ve eşi arasında empati geliştirme yoluyla okura yansıtılmıştır. Erkekliğin sorgulanması ve erkeklikle ilişkili deneyimlerin incelenmesi, toplumsal cinsiyet kavramıyla ilişkili şiddet eylemi ve kendilik deneyimi olgularının ve ikili zıtlıklarla ilişkili kavramların da sorgulanmasını beraberinde getirir. Öykünün sonunda ise, ana karakter olan erkek eşin, aynadaki aksine bakarak kendilik deneyimine ve kimliğine dair iç sorgulama gerçekleştirdiği ve öykünün de beklenmedik bir biçimde sona erdiği görülecektir:

Aynadakinin kim olduğunu anlayana kadar. Daha önemlisi, benim kim olduğumu anlayana kadar...

(Tosun 2013, 23)

Öykü içerisinde, cinsiyete dayalı farklılıkları vurgulayan ikili zıtlıklar, şiddet eğilimi, beden alg1sı gibi kavramlar üzerinden inşa edilen toplumsal cinsiyet tanımları sorgulanmaktadır. $\mathrm{Bu}$ noktada, erkeklikle ve kadınlıkla özdeşleştirilen belirli eylemler, ana karakterin sesinden okura yansıtılmıştır. Kadın eşin maddi şeylerle mutlu olduğunun sürekli vurgulanması ve her hafta başında kilo vermek için arkadaşlarıyla yarışa girmesinin aşağılanması, kadınlıkla ilişkilendirilen "sığlık" ve “iradesizlik” gibi düşüncelerle de koşutluk taşır. Öykünün sonunda ise, ana karakterin öykünün başından itibaren seslendirdiği ayrımcı düşünceler kullanılarak, erkek eşin aynada kendine bakma eylemi üzerinden erkekliğe ayna tutulduğu görülmekte ve bütün yaşananların ana karakterin zihninde üretilmiş bir kurgu olduğu okura yansıtılmaktadır. Bu açıdan, öykü, okurun kendi düşüncelerini sorgulamasına ve ayrımcı düşünce biçimlerine dair duyarlık geliştirmesine de ortam sağlamıştır.

Sonuç olarak, erkekliğin toplumsal olarak inşası üzerinden kurulan öykü, toplumsal cinsiyet kimliğinin, bu kimlikle ilişkili beklentilerin ve ayrımcı ve baskıcı düşünce biçimleriyle özdeşleşme kavramının ele alındığı bir öykü olarak inceleme içerisinde yerini almıştır. 
Bir sonraki başlıkta, Bir Nedene Sunuldum başlıklı kitaptan seçilen "Güzel Yüzlü Garsonlar" başlıklı öykü incelenecek; öykü içerisindeki geleneksel ataerkil düşünceyle ilişkili unsurlar mercek altına alınacaktır.

\section{“Güzel Yüzlü Garsonlar”}

Bir Nedene Sunuldum başlıklı kitaptan alınan öyküde, bir lokanta sahibi olan Azmi Efendi'nin gözünden, yaşamındaki bütün erkekleri kaybetmiş olan bir kadının, karşısına çıkan diğer erkeklerle kurduğu ilişkiler ve kadının gözünden de oğlu ve eşiyle yaşadıkları, lokantaya gelen kadın ve erkek müşteriler ve lokantanın erkek garsonları anlatılmaktadır. Bu açıdan, öykü, iki anlatıcılı bir özellik taşımaktadır. Kadın karakter, yaşamdan umudunu kesmiş, tek başına ayakta durmaya çalışan isimsiz biri olarak betimlenirken, Azmi Efendi'nin lokantanın sahibi ve garsonların başındaki usta olarak gösterilmesi, kadın ve erkek arasında kurulan hegemonyaya da göndermede bulunur. Azmi Efendi, dükkâna giren kadını, ilk etapta şu şekilde betimleyecektir:

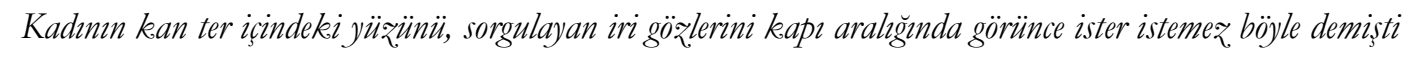

Azmi Efendi. Biraz.cekinerek. Ne de olsa yalnzyaşayan bir kadin. Son zamanlarda da iyice bir acayiplești.

Neme laz̦m,' diye geģiriyordu içinden. (Tosun 2015, 59)

Söz konusu betimlemenin temelinde, toplumsal yaşam içerisinde kadınların ve erkeklerin yaşama bakış açılarındaki farklılıkların vurgulanması bulunmaktadır. Toplumsal düzen, kadınları daha duygusal davranışlar sergileyen bireyler olarak toplumsal yaşam içerisinde konumlandırırken, erkekleri daha zor duygusal ilişki kuran ve zekâ ve aklını daha büyük oranda kullanan bireyler olarak konumlandırma eğilimi taşımaktadır. Azmi Efendi’nin, peşin hükümleri olan bir karakter olarak öykü içerisinde konumlandırılmışken, kadın müşterinin sorgulayan, anlamaya çalışan, mantıksal doğrulamayı gerçekleştirmeden ilişki kurmayan bir karakter olarak gösterilmesi bu durumla ilişkilidir.

Bir sonraki aşamada, kadınlık durumu ve duygu dünyası, Azmi Efendi’nin lokantaya gelen kadın müşterilere dair izlenimleri üzerinden şu şekilde öyküye dahil edilecektir:

Mümkünse kössede olmasm tercib ettikleri masalarna oturmadan evvel illaki "ben bir lavaboya gideyim" diyen genis basenli, terlemiş kadnlar,

Tüm o kadinlarn, saçlarm bir omu₹larndan alp ötekine koyarken yü̈lerine konduruverdikleri saskanca sub ifadeyi... (Tosun 2015, 59)

Kadınların, özellikle lokantadaki köşe masaları tercih eden, sürekli olarak saçlarıyla oynayan, lavaboya gitmeyi alışkanlık haline getiren bireyler olarak öykü içerisinde konumlandırılması, Cilt 1 / Say1 4

Aralı 2018 
yukarıda sözü edilen kadınlık algısıyla da koşutluk gösterir. Kadınların toplumsal mekânlarda bu türden eylemlerle dikkat çekmesi, mekândaki kadın varlığının sürekli olarak denetim altında tutulmasıyla da yakından ilişkili olarak değerlendirilmektedir. Bundan dolayı, kadınların davranışlarında izlenmenin ve denetim altında tutulmanın verdiği rahatsızlı̆ga dair izler görmek olası bir hal alır. Öykü içerisinde de, bu durum, lokantaya gelen kadınların ruh hallerine yansıtılmıştır.

Hissedilen rahatsızlığın bir sonraki aşaması ise, kadınların gizlenme gereksinimi hissetmeleri ve rahatsızlıktan kurtulma yollarına başvurmalarıdır. Gizlenme eyleminin, kadın karakterle ilgili olarak Azmi Efendi’nin sesinden şu şekilde ele alındığı görülür:

Günlïk sacmalıkları, ufak sıkintularm anlatmak isterdim. Sonra onunkileri dinlemek... Ama bic vakti olmazdr. Yazardı hep. Ne yazard, neden ve kime yazardı onca şeyi, hic anlamadim. Yazmadiğ zamanlarda da yüzünü hep bir kitabın arkasina gizlerdi. (Tosun 2015, 60)

Görünürlük/görünmezlik eylemi üzerinden ele alınan yukarıdaki duygu davranışı, kadının kitap arkasına gizlenme eyleminde kendini gösterir. Çünkü kendini uzaklaştırma eylemi ve etrafındakilerle ilişki kurmama eğilimi, kadınların cinsiyet ayrımcıllğına, şiddete, sözlü veya fiziksel tacize karşı koyma ve önlem alma konusunda başvurdukları eylemler olarak öyküde yer almaktadır. Kadın karakter de, bu türden eylemlerle karşılaşmamak için kendini gizlemeyi tercih etmektedir. Kadınların davranışlarının toplum içerisinde erkeklere oranla daha fazla denetim altında tutulduğuna vurgu yapan Deborah Cameron, "toplumsal cinsiyet temsillerinin takintıl bir biçimde kadinsiliğa odaklandiğm, temel etkinin erkeksiliği kültü̈rel olarak görünmez kilmak ol[duğunu], bö̈lece erkeklerin davranışlarmm sürekli olarak gözden uz̨akta kal[dığmı]” belirtmektedir (2014, 286).

Kamusal alanda kadınlar üzerinde kurulan baskının izleri, garsonları görüp kendi oğlunu anımsayan kadın karakterin, oğluna özlem duymasına rağmen hislerini açık bir biçimde ortaya koyamamasında da görülmektedir. Kamusal alanda kadınlar üzerinde kurulan denetim ve otokontrol kavramları aracılığıyla, öykü içerisinde kadınlık ve annelik olgusu arasında şöyle bir ilişki kurulduğu görülmektedir:

Kapalı kutuydu benim oğhum. Ben de aşmadım duvarlarm, aşamadm. Bir kę içimden coșan sevgime uyup sılkı sılkı saramadim örmeğin. (Tosun 2015, 61)

Ataerkil toplum düzeni, bir açıdan, kadınlığı annelik ve eşlik rolleriyle sınırlarken, başka bir açıdan da annelikle ilişkilendirilebilecek davranışları sınırlama eğilimi taşır. Yukarıdaki alıntıda da, bu sınırlama durumuna ilişkin gözlem aktarılmaktadır. Butler'ın belirttiği, “kadınlı̆ğm, bakıcılık, annelik, doğurganlık rollerinin de bir diæi başka islevle sinurlandırlma durumu”, kadınlı̆̆ın ve erkekliğin belirli 
beklenti ve normlar üzerinden tanımlanmış ve sınırlanmış halini bir kez daha ortaya koyar (1993, 53). Söz konusu öyküde hem erkek hem de kadın karakterlerin kendilerine dair sorgulamalarında bu durumun yansımalarını da görmek mümkündür. Azmi Efendi’nin erkeklikle ve toplumsal yaşamla ilişkili sorgulaması, öykü içerisinde şu şekilde yansıtılmıştır:

Adam 'ben neden buradayım?' dercesine sorar gǫ̈lerle bakıyordu kadina, davranıslarmm tümüne karınmıs o ezbere, kösseleri belirgin ve yalandan saygisim elbette unutmayarak. (Tosun 2015, 61)

Kimliğe dair sorgulama, ataerkil toplumun çok fazla istemediği ve gösterilmesine firsat tanımadığ1 eylemlerden biridir. Öykü içerisinde, karakterlere erkeklik ve kadınlık rollerine dair sorular sordurularak, okurun da içerisinde yaşadığı toplumun normatif olarak gördüğü ve ön kabul olarak yaşamına dahil ettiği birtakım olgu ve kavramları sorunsallaştırılmasına ortam hazırlanmıştır. Benwell ve Stokoe, "öznelerin toplumsal cinsiyetlendirilme, biyolojike cinsiyetlendirilme ve trksallasțtrlma sürecini anlamak için, gerekli düzenleyici kurgu olan kimlï̆i ve özdeşlesmeyi de anlamamı gerek [tiğini]” vurgularken, bu duruma da dikkat çeker $(2006,29)$.

Ataerkil yaşamda, kadınlar ve erkekler, kendilerine gösterilen rol modellerden birinin veya birkaçının özelliklerini alarak kendi kimliklerini inşa etme eğilimi gösterirler. Bu özdeşleşme süreci, bir oranda içselleştirilmiş baskı mekanizmalarını da içerir. Söz konusu baskı mekanizmalarına karşı duruş, kadın karakter aracılığıyla şu şekilde ele alınmıştır:

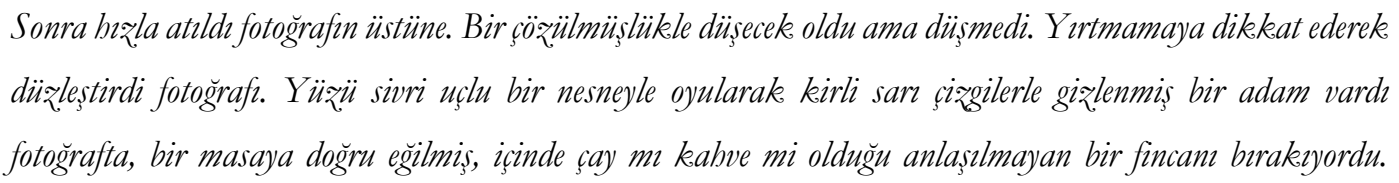
(Tosun 2015, 62)

Kadın karakter, fotoğraftaki eşinin gözlerini oyarak, ataerkil düzenden ve onun beraberinde getirdiği baskı mekanizmalanından, davranış kalıplarından simgesel olarak öcünü almıştır. Freud, "iğdis kaygısınm, babanın cinsel organlar altında ezilmenin yam sira, kendi cinsel organlarmmn da baba tarafindan tehdit edilmesine dayandiğmi” belirtirken, "fallusla özdeşleșme süreci ekseninde hem erkeklerin hem de kadınlarn iğdis edilme olasıliğmın ortaya ģık [tı̆̆ın]” vurgular $(1919,63)$. Bundan hareketle, öykü içerisinde, yalnızca kadın karakterin değil, diğer erkek karakterlerin de sembolik anlamda iğdiş edilme kaygısı içinde olduğu sonucuna varılmaktadır. Söz konusu durumla ilişkili olarak, kadının elinde tuttuğu ve başkalarından sakladığı fotoğraftaki adamın gözlerinin oyulmuş olması, kadının ataerkil düzenden ve baskı mekanizmalarından öç alırcasına bunu yanında taşıması, iğdiş etme veya edilme kaygısının yansımaları olarak görülmekte ve kadın karakterin erki elde etme isteğini yansıtmaktadır. 
Kadın karakter lokantanın müdavimlerinden biri olsa da, Azmi Efendi, yaklaşma cesaretini kendinde bulamaz çünkü kadın karakterin nasıl tepki vereceğine dair herhangi bir fikri yoktur. Kadını tanımadığı için temkinli davranır ve ilk adımın ondan gelmesini bekler. Kadın karakter ise, aile yaşamına ait birtakım eşyaların bulunduğu torbaları Azmi Efendi’ye vererek, geçmişin yüklerinden kurtulmak istemektedir. Bunu yapmak üzere lokantaya geldiğinde, aşağıda Azmi Efendi’nin sesinden verilen şu düşüncelerle de yansıtıldığı üzere, bu izlek kullanılarak, kadınlık ve erkeklik rollerine bağlı olarak ortaya çıkan düşünceler ve norm dışı davranış biçimlerinin gelişmesi önündeki engeller tartışmaya açılmıştır:

Adam kadmmn biraz kötü kokan soluğunu yüz̈̈̈nde bissediyordu. Kaçmak istiyordu, orası kesin, ama kadm bu halde burakmak da tuhaf kaçacaktı. Hem hažrladiğ, giysilerle dolu torbalar verecekti kadın, buraya bunun için gelmemis miydi zaten? (Tosun 2015, 63)

Norm dışı davranış biçimleri, toplumsal yaşam içerisinde devamlı olarak marjinalleştirilen ve ötekileştirmeye maruz bırakılan davranışların tümünü bir araya getirir ve kapsamında cinsiyetlerle ilişkili beklentileri barındırır. Bir kadının anne olarak davranışları, bir erkeğin baba ve aile reisi olarak davranışlanı, bir çocuğun anne ve babasıyla kurduğu ilişkiler, anne ve babanın toplumsal düzen içerisinde aileyi temsil ederken ortaya koydukları davranışlar ve ilişkiler bütünü ataerkil toplum düzeninin aile çevresinde bireyler üzerinde yarattığı baskının ürünüdür. Hem kadın karakterdeki belirsizlik hem de Azmi Efendi’nin yaşadığ1 tereddüt kullanılarak cinsiyet rolleri arasındaki keskin düşünsel, davranışsal ve duygusal ayrımlar ortadan kaldırılmış ve öykünün farklı kısımlarında her iki cinsiyet bu açılardan birbirine yaklaştırılmıştır. Bu yakınlaşma durumu, öykünün sonunda iki karakterin öpüşme eylemini gerçekleştirmesiyle somut bir görünüm kazanacaktır.

Sonuç olarak, Yalçın Tosun'un, bir ana karakter yaratmadan, bütün karakterlere öykünün belirli yerlerinde öne çıkma firsatı tanıyarak, öykü içerisinde karakterler arasında merkeziyetten uzakta, eşitlikçi bir ilişki kurduğu görülmektedir. Bu açıdan, hem Azmi Efendi karakteri hem de ismi belirtilmeyen kadın karakter arasında eşitlik kurulduğu, okurun dikkatinin bu eşitliğe çekildiği ve kurgunun her iki karaktere dair anlatısal özelliklerle şekillendiği sonucuna varılmaktadır. Kadın karaktere isim verilmemiş olması, gündelik yaşamda birçok iğdiş edilme eylemiyle karşılaşan kadınların durumunu yansıtmak açısından öneme sahiptir. Bununla birlikte, Azmi Efendi'nin isminin kullanılırken, kadın karakterin isimsiz bırakılması, toplumsal yaşamın farklı alanlarında egemenliği ellerinde tutan erkeklerin gücünü de simgeler. Yalçın Tosun, kadınlığa ilişkin önkabulleri ve erkekliği üstün gören hiyerarşik bakış açısını herhangi bir iyileştirme yapmadan öyküye yansıtarak, toplumsal cinsiyet bağlamında tarafsız bir bakış açısı yaratmış ve okurun erkek ve kadın 
arasındaki hiyerarşik toplumsal ilişkiyi de aşarak toplumsal cinsiyet eşitliği konusunda duyarlık kazanmasına aracılık etmiştir.

\section{Sonuç}

Yalçın Tosun, yaygın toplumsal cinsiyet algısıyla şekillendirilen basmakalıp düşünceleri, ikili zıtlıkları, baskı mekanizmalarını ilk kitabından itibaren olduğu gibi aktarmış ve okura ulaştırmış, bu sayede yenilikçi bir yazar olarak Türkçe yazın dizgesinde yerini almıştır. Yazarın öykülerinde kadınlar ve erkekler toplumsal düzlemde kendilerine biçilen kadınlık ve erkeklik rollerini yerine getirmeye çalışan, ancak bunu yaparken hırpalanan, çoğunlukla başarısız olan bireyler olarak ele alınmıştır. Bu açıdan, Yalçın Tosun öyküleri bütünsel olarak ele alındığında, ayrımcılık ve baskı mekanizmalarının ortaya çıkma biçimlerine dikkat çekildiği ve geleneksel ataerkil erkek ve kadın kimliklerinin belirli açılardan yansıtıldığı fark edilecektir. Yapılan çalışma içerisinde de yukarıdaki saptamaları destekleyen iki temel olguyla karşılaşılmıştır.

Bu olgulardan biri, geleneksel ataerkil erkeklik ve kadınlık kavramlarıyla ilişkilendirilen fiziksel ve ruhsal özelliklerin doğrudan yansıtılması veya bozuma uğratılmasıdır. Örneğin, "Her Şey Tarih Oluyor" öyküsünde, sünnetle inşa edilen fiziksel bir unsur olarak erkeklikle ilişkili "güçlü," "saldırgan," "kararlı” olmak gibi fiziksel özellikler, toplumsal cinsiyet inşası sürecinde Halil karakteri aracılığıyla bozuma uğratılmıstır. Böylece, ataerkil düzende erkeksilik ve kadınsılık kavramları arasındaki sınırların bulanıklaştırıldığı görülmüştür. Bu durumun da öyküye norm kırıcı bir özellik kazandırdığı sonucuna varılmıştır. "Altın Günü” öyküsünde de, ana karakter Mehpare Hanım aracılı̆̆ıyla, "makbul” kadın olmakla özdeşleştirilen iyi yemek yapabilme ve titizlik gibi özelliklerin okura yansıtıldığı görülmüştür. Ancak bu özelliklerin yanında, kadın karakterin, eşi olmadan hayatta kalmaya çalışan bir birey olarak öykü içerisinde konumlandırıldığı da fark edilecektir. Kadın karakterin, ataerkil düzende "evin reisi" addedilen (fakat, aslında evde çok y1kıcı bir etkisinin bulunduğu ortaya çıkan) erkeğin yokluğunda evin denetimini elinde tutar şekilde betimlenmesiyle, erkeğe atfedilen "kuruculuk" ve "koruyuculuk" gibi görevler de tartışmaya açılmıştır. Böylece, erkeklik ve kadınlık ekseninde kurulan hiyerarşik ilişki sekteye uğratılmıştır. Bu açıdan, öykü içerisinde, geleneksel ataerkil baskıcı ve ayrımcı kadınlık ve erkeklik rolleriyle inşa edilen toplumsal cinsiyet algısının bozularak eşitlik ekseninde yeniden inşa edildiği sonucuna ulaşılmıştır.

Geleneksel erkeklik ve kadınlık rolleriyle ilişkilendirilebilecek diğer bir olgu ise, toplumsal cinsiyete dayalı hiyerarşilerin ve ayrımların doğrudan yansıtılmasıdır. Örneğin, "Bir Kocanın Gizli Defterinden" başlıklı öyküde, sürekli olarak eşi tarafindan aldatılma kaygısı hisseden bir erkek eşin bakış açısından okura yansıtılan ayrımcılık ve hiyerarşi unsurlarının herhangi bir iyileştirme Cilt 1 / Say1 4

Aralık 2018 
yapılmaksızın aktarılmış olması, toplumsal bir kurum olarak erkekliğin içerisinde barındırdığ1 çelişkileri okura açık bir biçimde göstermiş ve okur karşısında gerçekçi bir tablonun çizilmesine ortam sağlamıştır. Bu sayede, öykü içerisinde, toplumsal cinsiyet kavramının, gözlemlere dayalı olarak inşa edildiği, bu durumun da okur için gündelik yaşama dair nesnel bir değerlendirme yapma firsatı yarattığı saptanmıştır. "Güzel Yüzlü Garsonlar” başlıklı öyküde ise, isimsiz kadın karakterin, ataerki tarafından iğdiş edilmiş bir kadın olarak, Azmi Efendi karakterinin ise "güçlü," "aklıselim,” “konum sahibi” bir erkek olarak öykü içerisinde konumlandırıldığı görülmüştür. Kadın karakter ve Azmi Efendi yoluyla okura yansitılan toplumsal cinsiyet kavramı, toplumsal erkeklik ve kadınlık kavramlarından temellerini alan ikili zıtlıklara dayalı olarak ve toplumsal yaşamda görünür hale gelen beklentiler bağlamında herhangi bir iyileştirme yapılmaksızın öykü içerisinde inşa edilmiştir. Bu bakımdan, öyküde, gözlemlere dayalı ve nesnel bir bakış açısının kullanıldığı, bu durumun da erkeklik ve kadınlık kavramları arasındaki ayrımları net bir çerçeve ile okura sunduğu sonucuna ulaşılmıştır. 


\section{KAYNAKÇA}

Aydın, K. (2013). Peruk Gibi Hüzünlü Herkes (Çevrimiçi). http://www.dinamikgazete.com/peruk-gibi-huzunlu-herkes/ Erişim Tarihi: 7 Ekim 2013.

Benwell, B.; Stokoe, E. (2006). Discourse and Identity. Edinburgh, Büyük Britanya: Edinburgh University Press.

Butler, J. (1993). Bodies That Matter: On the Discursive Limits of "sex." New York, ABD; Londra, İngiltere: Routledge.

Cameron, D. (2014). Gender and Language Ideologies. The Handbook of Language, Gender and Sexuality içinde s. 281-297. West Sussex, İngiltere: Wiley Blackwell.

Deleuze, G. (2003). Desert Islands and Other Texts (1953-1974) Semiotext(e). (Ed. David Lapoujade; Çev. Michael Taormina). Los Angeles, Kaliforniya: Semiotext(e) Foreign Agent Series.

Freud, S. (1919). Totem and Taboo: Resemblances Between the Psychic Lives of Savages and Neurotics. (Çev. A. A. Brill). Londra, İngiltere: George Routledge \& Sons, Limited.

Hall, D. E. (2003). Queer Theories. New York, ABD: Palgrave Macmillan.

Hall, D. E. (2004). Subjectivity. New York, ABD; Londra, İngiltere: Routledge.

Hall, S. (1997). Representation: Cultural Representations and Signifying Practices. Londra, İngiltere; Kaliforniya, ABD; Yeni Delhi, Hindistan: Sage Publications.

Holmes, J. (2014). Language and Gender in the Workplace. The Handbook of Language, Gender and Sexuality içinde s. 433-452. West Sussex, İngiltere: Wiley Blackwell.

Hükümenoğlu, H. (2013). Okuma Notları: Dokunma Dersleri, Yalçın Tosun (Çevrimiçi). http://hikmethukumenoglu.com/index.php/blog /dokunmadersleri/ Erişim Tarihi: 12 Kasım 2013.

Kulick, D. (2014). Language and Desire. The Handbook of Language, Gender and Sexuality içerisinde s. 68-85. West Sussex, İngiltere: Wiley Blackwell.

Lodge, D. (1995). Hélène Cixous: Sorties. Modern Criticism and Theory: A Reader içinde s. 286-293. London and New York: Longman.

Mills, S. (2004). Discourse. New York, ABD; Londra, İngiltere: Routledge. 
Tosun, H. (2015). Ötekilerin Kalemi: Yalçın Tosun (Çevrimiçi). http://kaybolandefterler.com/otekilerin-kalemi-yalcin-tosun/ Erişim Tarihi: 10 Şubat 2015.

Tosun, Y. (2009). Anne, Baba ve Diğer Ölümcül Şeyler. İstanbul: Yap1 Kredi Yayınları.

Tosun, Y. (2011). Peruk Gibi Hürünlüi. İstanbul: Yap1 Kredi Yayınlan1.

Tosun, Y. (2013). Dokunma Dersleri. İstanbul: Yap1 Kredi Yayınları.

Tosun, Y. (2015). Bir Nedene Sunuldum. İstanbul: Yapı Kredi Yayınları.

Yalçın, M. (2015). Bir Nedene Sunuldum (Çevrimiçi). http://www.edebiyat ortami.com/Bir_Nedene_Sunuldum_Yalcin_Tosun-120.html Erişim Tarihi: 2015. 